\title{
Vacuum dried membranes of poly (I-lactic acid) and bacterial cellulose for biomedical applications
}

\author{
Drielle Justiniano de Souza ${ }^{1 *}$, Luismar Marques Porto ${ }^{1}$, Ana Paula Testa Pezzin ${ }^{2}$ \\ From 5th Congress of the Brazilian Biotechnology Society (SBBIOTEC) \\ Florianópolis, Brazil. 10-14 November 2013
}

\begin{abstract}
Background
Periodontitis is the inflammation of tissues supporting the tooth when gingivitis is not treated [1]. The treatment should reduce/eliminate inflammation of the tissue, which is induced by the biofilm with its byproducts and correct anatomic defects caused by the disease [2]. Guided tissue regeneration is a technique that applies membranes that form a blood clot that may allow the growth and differentiation of cells and regenerate the periodontal tissues. This should be able to block and isolate the area and contribute passively to tissue integration with guaranteed protection, including possible bacterial contamination $[2,3]$. This work aimed to obtain biocomposites of poly(l-lactic acid) (PLLA) with bacterial cellulose (BC) by different methodologies to be applied as membranes for the treatment of periodontitis. The characterization was performed by scanning electron microscopy, cell adhesion and contact angle. It was observed that the membranes $80 / 20$ prepared by casting prior to vacuum drying of $\mathrm{BC}$ exhibited better adhesion. This membrane proved to be non-cytotoxic and more hydrophilic.
\end{abstract}

\section{Methods}

Biocomposites of PLLA/BC were obtained from four different methods (M1-M4). M1: solvent exchange with BC; M2: Vacuum dried BC, with ratio of PLLA/BC 80/20; in $\mathrm{M} 3$ and $\mathrm{M} 4$ we used $\mathrm{BC}$ lyophilized membranes. In the third method PLLA/ $\mathrm{CHCl}_{3}$ solution was poured over the $\mathrm{BC}$ membrane and in the fourth method PLLA/CHCl 3 solution was filtered on a Gooch funnel. The evaluation of the composite membranes was performed by the techniques of scanning electron microscopy, cell adhesion (Vero cell line, ATCC CCL 81, passage 192) and contact angle.

${ }^{1}$ Chemical Engineering Graduate Program, Federal University of Santa

Catarina, Florianópolis, Santa Catarina, 88040623, Brazil

Full list of author information is available at the end of the article

\section{Results and conclusions}

By visual inspection and the cell adhesion assay it was clear that the most satisfactory results were obtained for the membranes made with vacuum-dried BC/PLLA. On those membranes (M2 method), non-toxicity of the membrane was verified through the formation of a monolayer of adhered cells. Membranes obtained by this second method also showed more favorable results in decreasing the value of the contact angle, a consequence of the increasing hydrophilicity of the sample [5]. This membrane has a smooth surface and did not show toxicity to the cells by the addition of $\mathrm{BC}$. These requirements are important for a biomaterial to be used for medical purposes. In this work $\mathrm{BC}$ and pure PLLA membranes were prepared and combined to form composites aimed to biomedical applications. Particular attention was given to the resulting biomaterial so as to guarantee that it could be used in the human body, therefore meeting the necessary initial requirements, such as non-cytotoxicity, biodegradability and bioresorption. Taking into account that PLLA is a biodegradable and bioresorbable polymer and BC is highly hydrophilic, through the analysis of cell adhesion and contact angle we showed that the second preparation method was the most appropriate, that is, the one using vacuum dried BC. The seeded cells formed a monolayer, indicating satisfactory adhesion; on the other hand, no cytotoxicity of the membrane and enhanced hydrophilicity of the composite membrane were observed, allowing the use of this membrane for biomedical applications.

\section{Acknowledgements}

To CNPq, CAPES, FAPESC, FINEP, FAP/UNIVILLE.

\section{Authors' details}

${ }^{1}$ Chemical Engineering Graduate Program, Federal University of Santa Catarina, Florianópolis, Santa Catarina, 88040623, Brazil. ${ }^{2}$ Process Engineering Graduate Program, UNIVILLE, Joinville, Santa Catarina, 89219710, Brazil. 
Published: 1 October 2014

\section{References}

1. Cochran DL: Inflammation and bone loss in periodontal disease. J of Periodontology 2008, 79:1569-76.

2. Mendes RT: Efeitos cardiovasculares da inibição da ciclooxigenase-2 em um modelo experimental de periodontite induzida por ligadura. Dissertação de mestrado (Odontologia) - UEPG. Ponta Grossa; 2012

3. Schenk RK, Buser D, Hardwick WR, Dahlin C: Healing pattern of bone regeneration in membrane-protected defects: a histologic study in the canine mandible. International Journal of Oral and Maxillofacial Implants 1994, 9:13-29.

4. Yuan XW, Liu D, Easteal JA, Bhattacharyya D, Li J: Preparation of poly-(lactic acid) scaffolds reinforced with bacterial cellulose nano-fibres. 2010.

5. Svensson A, Nicklasson E, Harrah T, Panilaitis B, Kaplan DL, Brittberg M, Gatenholm P: Bacterial cellulose as potential scaffold for tissue engineering of cartilage. Biomaterials 2005, 26:419-431.

doi:10.1186/1753-6561-8-S4-P50

Cite this article as: de Souza et al:: Vacuum dried membranes of poly (I-lactic acid) and bacterial cellulose for biomedical applications. BMC Proceedings 2014 8(Suppl 4):P50

\section{Submit your next manuscript to BioMed Central} and take full advantage of:

- Convenient online submission

- Thorough peer review

- No space constraints or color figure charges

- Immediate publication on acceptance

- Inclusion in PubMed, CAS, Scopus and Google Scholar

- Research which is freely available for redistribution

Submit your manuscript at www.biomedcentral.com/submit 